\title{
From Content to Method: the Liber de causis in Albert the Great*
}

\author{
Katja Krause \\ Harvard University \\ Henryk Anzulewicz \\ Albertus-Magnus-Institut, Bonn

\begin{abstract}
The Liber de causis at the Heart of Albert's Philosophical Programme
\end{abstract}

It may not be an exaggeration to say that just as the prima causa enjoys ubiquitous presence in created reality according to the Liber de causis (henceforth: $L D C$ ), so does the $L D C$ itself enjoy a similar presence in Albert the Great's works. ${ }^{1}$ Ranging from his very first theological treatise, De natura boni (after ca. 12321234), to one of his very last philosophical works, the Problemata determinata (ca. 1271), the $L D C$ features in all of Albert's major treatises, regardless of their theological or philosophical intentions. ${ }^{2}$

The unmistakable climax of Albert's appropriation of the $L D C$ lies in his commentary on it, or rather in his creative fusion of commentary preceded by a hermeneutical framework. Written between 1264-1267, immediately after completing his commentary on Aristotle's Metaphysics, Albert devised his De causis et processu universitatis a prima causa by prefixing this hermeneuti-

* We would like to thank Steven Harvey (Bar Ilan University) for his most valuable comments on an earlier version of this paper. Katja Krause thanks the Leopoldina-Nationale Akademie der Wissenschaften for generously supporting the research on this paper.

1 Liber de causis, prop. I n. 1-2, p. 46.1-5: Omnis causa primaria plus est influens super causatum suum quam causa universalis secunda. Cum ergo removet causa universalis secunda virtutem suam a re, causa universalis prima non aufert virtutem suam ab ea.

2 Albert quotes the $L D C$ for the first time in his first writing, De natura boni, only once. Albert the Great, De natura boni, p. 76.16-18: dicit Philosophus, quod 'omnis virtus unita plus est infinita' et fortis 'quam virtus multiplicata'; cf. Liber de causis, prop. XVI(XVII), p. 83.15-16. In his latest work, Problemata determinata, Albert explicitly refers to propositions I, III, IV, XVIII(XIX), $\mathrm{XIX}(\mathrm{XX}), \mathrm{Xx}(\mathrm{XXI}), \mathrm{XXVI}(\mathrm{XXVII})$ and implicitly to propositions I und v; cf. Albert the Great, Problemata determinata, p. 97 and 99 (Index auctorum). 
cal framework, which supplemented the insights contained in the $L D C$, with reflexions on the nature, characteristics, and activity of the prima causa in close reliance on Al-Ghazali's Metaphysics. ${ }^{3}$ In its articulated systematic purpose, Albert's commentary on the $L D C$ complements Aristotle's Metaphysics XI (lambda) in the Latin translation, and thus concludes his philosophical programme of real philosophy (philosophia realis). ${ }^{4}$ Initially, though, Albert had not planned to assign the $L D C$ any systematic purpose within his own philosophical programme, which he began to write around 1250 by commenting on Aristotle's Physics. Yet when he concluded his commentary on book XI of the Metaphysics, he came to realise that demonstrative proofs concerning the principles of substance, motion, and movers of the heavens were lacking, and he observed the danger of certain conflations between philosophical and theological arguments concerning these matters. As a consequence, Albert inserted his De causis et processu universitatis a prima causa into his overall philosophical programme. ${ }^{5}$ This is why the De causis not only temporally concluded

3 Concerning Albert's perceived requirement of completion of the science of metaphysics, $\mathrm{cf}$. Albert the Great, Buch über die Ursachen, Anzulewicz et al. (trans. and eds.), p. xxix-xxxiv; Petrus de Prussia, Vita B. Alberti Magni, p. 298. Concerning the Latin translation of Aristotle's Metaphysics that Albert used, cf. Vuillemin-Diem 1975, p. 7-69.

4 Albert the Great, Metaphysica, 11.3.7, p. 541.90-542.6 (see following note); and Albert the Great, De causis et processu universitatis a prima causa 2.1.1, p. 59.22-6o.5.

5 Albert the Great, Metaphysica 11.3.7, p. 541.90-542.31: Sed quia nobis incerta sunt tria circa ea quae moventur, ideo dubitavit Aristoteles de omnibus illis et non certificavit ea per demonstrationem. Incertum enim est nobis, utrum unum corpus pluribus moveatur motibus an uno tantum. Incertum etiam nobis est, utrum ab uno corpore, quod est stella, virtus motiva fluat in orbem an stella moveatur motu orbis sui tantum et non per se. Incertus etiam nobis est numerus corporum caelestium motorum cum motibus suis. Et ideo Aristoteles dubie locutus est de illis, per rationem autem certam nihil potest comprehendi esse extra hoc. Et ideo de illis penitus aut nihil dixit aut etiam talia esse reprobavit. Quidam autem neutram istarum sequuntur viarum, putantes incedere in via philosophiae, et confundunt philosophiam in theologiam dicentes, quod in veritate ab uno simplici primo agente per essentiam non est nisi unum. Si ergo, quod est ab ipso, sit multum et multiplex, non agit per essentiam. Videmus autem unum caelum non produci in esse per alterum nec omnino generari caelum ex materia et ipsum esse multiplex valde. Oportet igitur, quod producatur in esse per aliquid agens per electionem. Hoc enim agit multa, unum existens, sicut vult, et causat ex nihilo, cum non indigeat praeiacente materia propter excessum infinitae virtutis ipsius super omne agens. Sed sicut nos iam in antehabitis protestati sumus, nos istas positiones non prosequimur, quia non suscepimus in hoc negotio explanare nisi viam Peripateticorum. Quaecumque autem Plato dixit, habeant firmitatem, quam possunt, donec forte ab aliquo explanentur. Theologica autem non conveniunt cum philosophicis in principiis, quia fundantur super revelationem et inspirationem et non super rationem, et ideo de illis in philosophia non possumus disputare. Quaecumque autem alia hic dicenda forent de substantia mobili et sensibili, sed incorruptibili, in I et II libro De caelo et mundo sunt explanata. Albert the Great, De causis et processu universitatis a prima causa, 2.1.1, p. 59.37-60.5: determinatur 
Albert's ambitious commentary project on Aristotle's works (including pseudoAristotelian works, such as the $L D C),{ }^{6}$ but also anchored it scientifically and crowned it as the very foundation of philosophia realis. ${ }^{7}$ The $L D C$ thus achieved the maximal point of significance in Albert's scientific edifice, a significance of methodological primacy over Albert's complete codification of the corpus Aristotelicum that can hardly be overestimated.

Yet, as we know all too well with our own work, every crowning achievement has its own history - a history that is usually characterised by less advanced and less developed stages. Such a history is also the history of the $L D C$ in Albert's appropriation thereof. But what exactly are these less advanced and less developed stages? How can they best be characterised? And how did they lead to the methodological primacy of the $L D C$ over all scientiae reales? The primary purpose of this paper is to shed light on Albert's appropriation of the $L D C$ into his own system of thought as it evolved, and to consider the key developments in the beginning stages of it. In so doing, we hope to show that these early stages of Albert's appropriation of the $L D C$ provide us with crucial insights into his growing interest in this source as the systematic foundation of his overarching scientific edifice. Indubitably, in a paper as short as ours, we can only provide a glimpse of a history that is marked by great complexity. For not only does Albert's appropriation of the $L D C$ advance and develop as we proceed chronologically in our study of his works, but so too does his own system of thought - and, unsurprisingly it does so in light of his evolving appreciation of the $L D C$ in different contexts, in different ways, and with different ends in mind. Such a complexity of interrelations raises the question of how we can best make sense of the history of Albert's appropriation of the $L D C$. In recognis-

hic de separatis substantiis secundum plenam veritatem, de quibus in XII et XIII Metaphysicae non nisi secundum opinionem determinavit Aristoteles. Propter quod et iste liber Philosophiae primae coniungendus est, ut finalem ex isto recipiat perfectionem. Ibid., 2.5.24, p. 191.17-23: In hoc ergo libro ad finem intentionis pervenimus. Ostendimus enim causam primam et causarum secundarum ordinem et qualiter primum universi esse est principium et qualiter omnium esse fluit a primo secundum opiniones Peripateticorum. Et haec quidem quando adiuncta fuerint XI Primae philosophiae, tunc primo opus perfectum est.

6 Even though Albert was aware that the $L D C$ was not a genuine work of Aristotle himself, he took its propositions to come from Aristotle and the commentaries to be composed and compiled by later Peripatetic thinkers. Cf. Albert the Great, Buch über die Ursachen, p. XXVIIXXVIII.

7 Albert the Great, Physica, 1.1.1, p. 1.43-49: Cum autem tres sint partes essentiales philosophiae realis, quae, inquam, philosophia non causatur in nobis ab opere nostro, sicut causatur scientia moralis, sed potius ipsa causatur ab opere naturae in nobis, quae partes sunt naturalis sive physica et metaphysica et mathematica, nostra intentio est omnes dictas partes facere Latinis intelligibiles. 
ing the potential shortcomings of our approach, we take as our analytic tools the notions of 'significance' or 'weight', perceived in terms of quantity, place, and manner. These three ways of perceiving significance or weight will aid us in elucidating the proliferations and intensifications of Albert's appropriation of the $L D C$ in a clear and structured way.

Under these conditions, then, we proceed by turning to what we have identified as the first phase of Albert's appropriation of the $L D C$, a phase which encompasses his scholarly activity prior to the Parisian period. In the first section, we uncover Albert's initial integration of select propositions of the $L D C$ into the context of biblical theological subject matters, and identify them as decontextualized or 'dissociated transformations' of ideas. We show how in this phase, Albert did not grant the $L D C$ an autonomous significance in terms of content, but rather put formal-systematic characteristics of individual propositions into the service of explaining moral and systematic theological themes. Subsequently, we turn to the second phase of his appropriation, now in Paris, and single out one particular work of his, the Summa de creaturis with its two parts, De IV coaequaevis and De homine. In this second section, we reveal how Albert begins to integrate key propositions of the $L D C$ into his own understanding of the world's coming-to-be, and thus grants the $L D C$, for the first time, an autonomous significance in terms of its genuine content. This 'anchored transformation', as we call it, of the insights contained in the $L D C$ - a transformation characterised by "persistence in an original or closely related scientific context, and attachment to a native research question"-represents a key condition under which Albert was able to move beyond significance in content toward significance in method. ${ }^{8}$ In the third section, we briefly turn to the final phase of Albert's early appropriation of the $L D C$. Here, in his commentary on the Sentences, we find Albert implement a second key move on his path toward the $L D C$ 's significance in method: the clear division of the sciences of theology and philosophy.

\section{$2 \quad$ Albert's Pre-Parisian Appropriations of the Liber de causis}

It was most likely during his initial period of lecturing in the Teutonian province at the Dominican Order's convents in Hildesheim, Freiburg, Regensburg, and Strasbourg that Albert composed his first scholarly work, the De natura boni (ca. 123os). In heavy reliance on a paraenetic approach, this moral theologi-

8 Krause 2015, p. 176. For the use of the two expressions 'dissociated transformation' and 'anchored transformation' as a methodological distinction, see: Krause 2015, p. 175-217. 
cal treatise examines the concepts of a virtuous life and right ethical conduct. Shortly after completing this treatise, and in line with the second pillar of the theological commentary practices of his days, Albert composed three systematic theological treatises for his early lecturing activities: the first redactions of the De sacramentis, De incarnatione, and De resurrectione. These have been dated with high probability to his pre-Parisian period before $1242 .{ }^{9}$ In all four treatises, the $L D C$ is present in a rather limited way and highly decontextualized from its original meaning and purpose. Only six of the thirty-one propositions of the $L D C$ can be found in these treatises, all in highly isolated contexts which draw on them, mostly for the purpose of expounding biblical or systematic theological themes by way of philosophical authority. Yet already we can discern a clear development with regard to place and manner of appropriation.

In Albert's De natura boni, we were able to identify proposition XVI(XVII) as the only case of appropriation from the $L D C$ : omnis virtus unita plus est infinita quam virtus multiplicata..$^{10}$ Albert uses this proposition in order to illustrate the biblical concept of 'overshadowing' as pertinent to the annunciation for Mary's immaculate conception, and he reasons that this is in analogy to our every-day experience of the effects that shadows have on our vision if there is an excess of sunlight. Just like they concentrate or unify our visual capacity, so too does the biblical overshadowing concentrate in its unifying powers for the annunciation. ${ }^{11}$ This biblical context is, of course, far from the original context and meaning of this proposition in the $L D C$. But Albert's principal interest seems to lie in the formal aspects of the $L D C$ 's isomorphism between unity and power as attributes of first and secondary causes alone, an interest that may well have led him to decontextualize proposition XVI entirely from its original context. ${ }^{12}$

9 Cf. Rigo 2005, p. 325-374; "Einleitung. Zeittafel" 2011, p. 9-31, esp. p. 12-13 and 28. Albert most probably finished these three systematic theological works in Paris. Concerning these two common practices of the theological commentary tradition (moral and systematic theology), cf. Leinsle 2010, p. 43-54, esp. p. 52-54 for the Dominicans; Anzulewicz 2010, p. 17-30.

$10 \quad$ Liber de causis, prop. XVI(XVII) n. 138, p. 83.15-16.

11 Albert the Great, De natura boni, p. 76.7-8.12-21.27-28: Secundum est, quod umbra visum colligit. [...] Secundum autem habet ex hoc quod ei proprium est colligere et unire lumen oculorum ex congregatione radiorum, et tunc virtus oculi congregata et unita fortior est quam sparsa et multiplicata, quia dicit Philosophus, quod 'omnis virtus unita plus est infinita' et fortis 'quam virtus multiplicata'. Huius evidens signum est, quod cum volumus acute videre et fortiter, ad supercilia ponimus latitudinem manus, ut umbra manus visus collectus fortior efficiatur. [...] Et secundum has proprietates 'virtus altissimi obumbravit' gloriosae virgini. Cf. also Anzulewicz 1998, p. 253-255.

See note 8. Other contexts of Albert's early reception of proposition XVI(XVII) reveal sim- 
As we progress in Albert's early works, we find such a decontextualizing use of individual propositions from the $L D C$ to be the rule rather than the exception. Albert's first systematic theological treatise, De sacramentis, draws on proposition I together with its accompanying commentary: omnis causa primaria plus est influens super causatum suum quam causa universalis secunda. ${ }^{13}$ Located in a sed contra as the first authority before Augustine's De baptismo puerorum, its principal purpose is to account for the hierarchical order of the sacraments. In systematic analogy to the first cause of the $L D C$, Albert presents the sacrament of baptism as the first, perse, and necessary cause in the order of the sacraments upon which all subsequent sacraments depend in their causal efficacy. ${ }^{14}$ In its original meaning of the $L D C$, proposition I has, of course, no thematic relation to the order of the sacraments, but is rather concerned with the relationship of the first universal cause of all there is to the subsequent primary causes. Yet Albert's analogous use of it reveals his salient attention to its formal-systematic characteristics in their flexible applicability to new thematic contexts.

Albert establishes a similar formal decontextualization in the same treatise with regard to proposition XXIII(XXIV) of the LDC: causa prima existit in rebus omnibus secundum dispositionem unam, sed res omnes non existunt in causa prima secundum dispositionem unam..$^{15}$ This time, however, he draws on it in his reply to an objection rather than in a sed contra argument. In connecting proposition XXIII(XXIV) to pseudo-Dionysius' statement from his De

ilar decontextualising tendencies. In his commentary on Peter Lombard's Sentences, for instance, Albert draws on this proposition as an axiom or as criterion for the validity of a certain statement. In his treatise on God, Albert draws on proposition XVI(XVII) to justify the infinity of God's power and action (cf. Sent. I.43.1, p. 378a). In his treatise on the sacraments, Albert relies on proposition XVI(XVII) as major premise to account for the unified order of the sacraments due to its fullness of power (cf. Sent. IV.24.2, p. 32a-b). Last but not least, it serves him to support the thesis that the human soul is capable of achieving full unity once disembodied in the afterlife (cf. Sent. IV.49.11, p. 684a).

13 Liber de causis, prop. I n. 1, p. 46.1-2.

14 Albert the Great, De sacramentis, 1.5, p. 12.52-67: Item, in ordine causarum illa dicitur causa prima quae causalitatem habet per se et aliis dat causalitatem, ita ut aliae non causent nisi cum ipsa et quodammodo virtute ipsius, sicut dicit Philosophus in principio Libri de causis, quod 'causa primaria plus influit quam secundaria'. Influit enim per se et sine secunda et iterum in secunda, sicut patet in exemplis ibidem positis: esse, vita et sensus, quae sunt causae formales ordinatae. Et patet, quod causalitas esse potest causare sine causalitate vitae et sensus, sed non e contrario. Subtracta enim vita adhuc remanet esse, sed non: subtracto esse remanet vita. Sed probabo, quod causalitas baptismi est per se, et nullius alterius sacramenti causalitas est sine baptismo. Ergo in ordine causarum, quae sunt sacramenta, baptismus est causa prima.

Liber de causis, prop. XXIII(XXIV) n. 176, p. 97.20-23. 
divinis nominibus that ipsa quidem [trinitas] universis adest; non omnia autem ipsi adsunt ${ }^{16}$ Albert accounts for the systematic theological theme of unique substantial change in Eucharistic transsubstantiation, and he reasons that although this change affects the underlying subject of bread and wine, it does in no way affect Christ's body. ${ }^{17}$ Formally speaking, proposition XXIII(XXIV) may well be said to fulfil a similar purpose as in the $L D C$, where it accounts for unified versus participating inherences. Thematically speaking, however, its main purpose in the $L D C$ is to illustrate the difference between the unified inherence of the first cause in all things in accordance with its universal presence and the ascending participation of all caused things in this first cause in accordance with their limited receptivity. Once again, Albert relies on a proposition from the $L D C$ in formal-systematic and decontextualizing terms, but this time in clear position to reinforce his own theological argumentation and in connection to other authorities. ${ }^{18}$

An even more prominent argumentative positioning of the $L D C$ and a more skilful connection with other authorities emerge from Albert's appropriation of proposition VIII(IX) in his De incarnatione: et intelligentia est habens yliathim

16 Pseudo-Dionysius the Areopagite, De divinis nominibus, c. 3, p. 138.6-7; trans. Ioh. Sarraceni: Dionysiaca, I, p. 122; Albert the Great, Super Dionysium De divinis nominibus, c. 3, p. 101.64 .

17 Albert the Great, De sacramentis, 5.1.3.2, p. 6o.25-35: transmutatio ista non est nisi in uno termino-alter enim terminus intransmutabilis est-, sed est in uno respectu alterius. Causa autem huius est, quod dicit Philosophus et beatus Dionysius, quod primum in omnibus est aequaliter et omnibus adest aequaliter, sed non omnia aequaliter sunt in ipso nec omnia aequaliter adsunt ei. Cum igitur corpus Christi sit unitum deitati, a divinitate habet hoc quod ipsum manens immotum sit uno et eodem modo se habens. Transmutatio autem fit in eo quod est ad ipsum et sub ipso, scilicet in pane et vino. For parallel texts, cf. Albert the Great, De resurrectione, 1.1, p. 240.24-27; ibid. p. 241.33-36; ibid. 2.1, p. 26o.6-19 (see following note); De homine, p. 595.32-49; Super Dionysium De divinis nominibus, c. 3, p. 105.45-64; Super Dionysium De caelesti hierarchia, c. 13, p. 192.87-193.4; ibid. p. 200.44-45; Super Matth., XI.26, p. 36o.64-71. Albert also quotes this proposition implicitly in Metaphysica III.3.9, p. 148.18-20; ibid. III.3.15, p. 155.65-72.

18 Proposition XXIII(XXIV) also features in Albert's De resurrectione in the thematic context of the resurrection where it is meant to account for the double efficient causality of God and Christ; cf. Albert the Great, De resurrectione, 2.1, p. 26o.6-19: [...] dicimus, quod nihil prohibet duo referri ad causam primam ut immediate et tamen unum esse ab altero. Aliter enim est in causa prima et in causis proximis naturalibus, quia dicit Philosophus, quod prima causa aequaliter adest omni rei, et ita non est mediata alicui. Unde natura et effectus naturae immediate sunt a deo, et tamen unum est causa alterius, licet non eodem modo causalitatis, sed natura est conformis causato suo, causa autem prima 'eminens proprietatibus causati'. Similiter dicimus hic, quod Christus resurgens inquantum huiusmodi est causa conformis nostrae resurrectionis, sed deus est causa eminens proprietatibus resurgentium, et tamen utraque immediate est a deo. 
quoniam est esse et forma et similiter anima est habens yliathim. ${ }^{19}$ Embedded in the context of two Aristotelian definitions of materiality and receptivity, Albert explains that the soul of all humans, including Adam and Christ, is 'receptive by nature' (anima passibilis est per naturam). Materiality, however, can be said in a number of ways, of which only the third way as propounded by proposition VIII(IX) of the $L D C$ is applicable to the human soul:

In the third way, it is called matter, as it has a receptive nature [ratio] because it is an individual thing [hoc aliquid] with regard to any form, be it that it is a form of nature or a form of intention. And in this way, it is understood in the Liber de causis where it is said that an intelligence is composed of hyliatico and form. And, therefore, said as matter largely speaking, the soul has a nature [ratio] of matter and a nature [ratio] of imperfection, not with regard to its substantial form, but with regard to the accidental forms. ${ }^{20}$

The Arabic notion yliathim (including all its cognates and implying 'determination' in its original meaning) was merely transliterated in Gerard of Cremona's Latin translation, and remained undefined in its meaning there. ${ }^{21}$ Latin authors, including Albert the Great and Thomas Aquinas, mistakenly identified its meaning as 'matter' or 'receptivity' in false etymological association with the Greek hyle, rather than as a formal attribute of the intelligence. ${ }^{22}$ Yet Albert's explanation in our passage above clearly reveals the 'skilful interpretation' of this difficult term that is usually ascribed to Thomas Aquinas. For he conceives of yliathim in an immaterial receptive way with regard to the human soul-a

19 Liber de causis, prop. VIII(Ix) n. 9o, p. 69.00-2: Et causae quidem primae non est yliathim, quoniam ipsa est esse tantum.

20 Albert the Great, De incarnatione, 6.1.1, p. 219.46-47: Pati est dispositio materiae, ut dicit Philosophus; ibid. p. 220.8-12: si volumus generaliter sustinere dictum Philosophi, dicimus, quod materia dicitur ibi, non sicut sumitur in naturis, sed dicitur materia, quod proprietatem materiae habet in hoc quod potest esse in ratione subiecti. Dicitur enim materia tribus modis. Cf. Aristotle, De generatione et corruptione, I.7 (324a1-3). Albert the Great, De incarnatione, 6.1.1, p. 220.22-29: Tertio modo dicitur materia, quod habet rationem suscipientis per hoc quod est hoc aliquid, respectu cuiuscumque formae, sive illa sit forma naturae sive intentionis. Et sic sumitur materia in commento Libri de causis, ubi dicitur, quod intelligentia est ex hyliatico et forma. Et sic, largo modo dicta materia, anima habet rationem materiae et rationem imperfecti, non respectu formae substantialis, sed accidentalis.

For the Arabic term yliathim cf. Baumgarten 2003, p. 161-171; D'Ancona Costa 199o, p. 327351; Fidora/Niederberger 20o1, p. 169-171; Caparello 1996, p. 72-75; Madec 1984, p. 119-121; Taylor 1979, p. 5o6-513; Id. 1998, p. 217-239. 
way that he may have likely been familiar with through his reading of Averroes' Long Commentary on the De anima. ${ }^{23}$ Although applied to a Christological context and yet again decontextualized from its original meaning, Albert's use of proposition VIII(IX) here reveals an important advancement in his manner of appropriation. Featured in a crucial explanatory reply and in immediate synthesis with Aristotelian definitions on the same theme, we can see how Albert shapes his systematic theology in reliance on an increasingly philosophical substantiation in which the $L D C$ plays an evolving role. ${ }^{24}$

A similar synthetic integration of the $L D C$, yet in application to the more general theme of anthropology can be witnessed in Albert's De resurrectione, where he incorporates proposition XVII(XVIII) - vita est processio procedens ex ente primo quieto, sempiterno, et primus motus - into his solutio to the question about the nature of eternal life. ${ }^{25}$ Following upon three other definitions of life, (1) the biblical-Christian teleological conception with reference to the beatific vision, (2) the Aristotelian conception as motion of a vegetative genus following nature, ${ }^{26}$ and (3) Alfred of Sareshel's definition as "continuous act of the soul in relation to the body", Albert defines the fourth meaning of life in reliance on this proposition as "the procession proceeding from the first being which is always at rest and eternal". ${ }^{27}$ While this definition of life was still absent from

23 Cf. for instance Averroes, In De anima, III.5, p. 387.7-11 and 387.22-388.32: Cum declaravit quod intellectus materialis non habet aliquam formam materialium, incepit diffinire ipsum hoc modo, et dixit quoniam non habet naturam secundum hoc nisi naturam possibilitatis ad recipiendum formas intellectas materiales. [...] Deinde dixit: non est in actu aliquod entium antequam intelligat. Idest, diffinitio igitur intellectus materialis est illud quod est in potentia omnes intentiones formarum materialium universalium, et non est in actu aliquod entium antequam intelligat ipsum. Et cum ista est diffinitio intellectus materialis, manifestum est quod differt apud ipsum a prima materia in hoc quod iste est in potentia omnes intentiones formarum universalium materialium, prima autem materia est in potentia omnes iste forme sensibiles non cognoscens neque comprehendens.

24 For Albert's appropriation of proposition $\mathrm{Ix}(\mathrm{x})$-omnis intelligentia est plena formis - in his De incarnatione, cf. the following section.

25 Albert the Great, De resurrectione, 4.2.2, p. 341.38-41: Item, in commento Libri de causis super illam propositionem: 'Res omnes habent essentiam etc.': 'Vita est processio procedens ex ente primo quieto, semper, aeterno, et primus motus'. Liber de causis, prop. XVII(XVIII) n. 145, p. 85.46-47. This definition of life is equally present in another early work of Albert the Great, IV Sententiarum 46.5, p. 633b, p. 634a-b; ibid. 46.6, p. 635b. Cf. Anzulewicz 1998, p. 37-39.

26 Cf. Aristotle, Top. vi.1o (148a26-28).

27 Albert the Great, De resurrectione, 4.2.2, p. 341.77-342.22: Sicut est principium vitae naturalis intrinsecum et unitum ei quod habet vitam, et hoc est anima vel spiritus, secundum quod dicimus angelos et daemones habere vitam naturae: sic est principium, quod est causa vitae aeternae, intrinsecum quidem, sed distinctum per essentiam, quia totum est intra et totum 
his earlier systematic theological treatise De sacramentis, which concentrated more on the physiological and ethical perspectives of life, Albert now considers human life holistically by including its transcendent origin and telos. ${ }^{28}$ Indeed, in analogy to the intrinsic principles of this-worldly life, the human soul and intellect, it is also God, the cause of eternal life, who is 'intrinsic' to the human soul and intellect, albeit not essentially. This advanced synthetic stage of appropriation of the $L D C$ in Albert's pre-Parisian period marks its culmination, yet again it is evident that his use of proposition XVII(XVIII) remains thematically unrelated to its original meaning in the $L D C$, where it serves to demarcate the causative act of the first cause (per modum creationis) modally from the causative acts of the secondary causes (per modum formae). ${ }^{29}$

In sum, then, Albert's pre-Parisian appropriation of individual propositions from the $L D C$ is limited to six propositions and is marked by qualitative decontextualizations. Albert's appropriations during this phase are exclusively characterised by a concentration on formal-systematic aspects of individual propositions, which are then put into service for explications of moral and systematic theological themes. At the same time, the individual propositions of the $L D C$ move to more and more prominent settings in Albert's works, leaving the argumenta rather quickly, migrating via the sed contrae and responsiones to the solutiones at the very heart of Albert's argumentation. With this changed position in the argumentative structure, the $L D C$ is increasingly connected to other authorities, anticipating Albert's integrative approach to the material at hand. But what happens when Albert begins to discuss theological themes closely related to the $L D C$ 's own concerns? How can we characterise its significance and weight then? To answer these questions, we turn to the next stage of Albert's early appropriation of the $L D C$.

est extra; quod est deus. Unde vita aeterna nihil aliud est quam immediata participatio primi motus a principio coniuncto per modum gloriae, quod est deus. Et dico 'immediate' propter vitam naturae, quam facit deus in anima vel spiritu, ut in angelo. Et dico 'primi motus' in ordine motuum vitae, quia sicut in ordine causarum prima causa est, quam omnes sequentes supponunt in causando et ipsa non supponit aliquam —unde etiam propter sui simplicitatem non est diffinibilis nisi per posterius, sicut est ens-, sic in ordine motuum vitae primus est, quem omnes reliqui supponunt, et ipse non supponit aliquem ex eis. Et ideo simplicissimus est et non diffinibilis nisi per posteriores, ut patet in exemplis: vivere, nutrire, augmentare, generare, intelligere, sentire, moveri processive; omnes sequentes supponunt vivere, et ipsum non supponit aliquem sequentium. Et dico 'coniuncti per modum gloriae', quia licet a deo sit omnis vita, non tamen ab ipso solo habent hunc motum, sed etiam ab alio principio quod est creatum ab eo, sicut est spiritus vel anima, eo quod in talibus non est nisi essentialiter, praesentialiter et potentialiter, et non per modum glorificantis.

28 Cf. Anzulewicz 1998, p. 35-49; Id. 200o, p. 611-612. Anzulewicz / Rigo 2002, p. 388-416.

29 Liber de causis, prop. XVII(XVIII) n. 148, p. 86.54-59. 
Beginning with his treatise of the Summa de creaturis, which was meant to synthesise theology and philosophy in a holistic worldview and which comprises the two well-known treatises De IV coaequaevis and De homine, Albert implemented many more insights found in the $L D C$ into the strongly overlapping systematic contexts of creation and anthropology. In its overall structure and method, Albert's Summa de creaturis relied on the near-contemporary theological Summa de bono by Philip the Chancellor (d. 1236). Yet in its thematic content it is, to a large extent, a foray into the previously uncharted territory of the philosophical writings of Aristotle and the Peripatetics. Albert's Summa de creaturis indeed aimed at proposing a unifying and systematically coherent account of theological and philosophical viewpoints concerning the two fundamental themes of creation and anthropology, and to determine the synthetic truth of these matters. ${ }^{30}$ In order to decide on this truth, Albert had to incorporate a large panoply of sources. But which of the seemingly unlimited insights contained in these sources would have to be integrated where and how? And how should any of these insights be interpreted in light of his own intention to reveal the synthetic truth of theology and philosophy? These choices of integration and interpretation presented an especially challenging task for Albert in his Summa de creaturis, since they more often than not seemed to require reconciling the irreconcilable.

Albert, nonetheless, faced up to this task with considerable scholastic flexibility and dedication, and, to a great extent, relied on the $L D C$ in so doing. Contrary to his pre-Parisian period, Albert's reliance on the $L D C$ thus sees a steep quantitative increase in his Summa de creaturis. As far as we can tell, Albert quotes the $L D C$ twenty-five times explicitly in his De IV coaequaevis, referring to fourteen different propositions. Similarly, in his De homine Albert quotes the $L D C$ thirty-four times, again referring to fourteen propositions, nine of which were cited in the De IV coaequaevis as well. ${ }^{31}$ More important than quantitative increases are place and especially manner of Albert's reliance on the $L D C$. Despite maintaining a number of decontextualizations of individual propositions and despite discussing a number of them in less prominent settings such as the argumenta and sed contrae, a fundamental development in Albert's appropriation is evident. For the first time, the $L D C$ becomes a lead authority in his argumentation in a context closely related to the concerns of

3о Cf. Anzulewicz 2011, p. 382-397, esp. p. 384-386.

31 See Appendix. 
the $L D C$ itself; in other words, Albert grants the $L D C$ an autonomous relevance in terms of content which he did not grant this work previously in his decontextualizing appropriations in his pre-Parisian period.

This is particularly the case in two thematically related solutiones of Albert's De IV coaequaevis: the first is concerned with the question of whether "the intrinsic mover, which is indivisible in quantity and motion, is a celestial soul or not?"; the second is concerned with the question of whether "the angels understand by species, and if so, what are these?"32 In reply to the first question, Albert bundles together four different propositions from the $L D C$ propositions VII(VIII), XII(XIII), XIV(XV), and XXII(XXIII) - and in his reply to the second question, he relies heavily on proposition $\mathrm{IX}(\mathrm{x}) \cdot{ }^{33}$ The use of these five different propositions in these solutiones may be considered a decisive development vis-à-vis his earlier inclusions. More interesting, however, is the fact that the solutions deal with the very same theme that the $L D C$ does, namely celestial intelligences and their causal activity. In his earliest systematic work, Albert thus adopts insights contained in the $L D C$ as the truth on the matters of the world's coming-to-be. It is this adoption that can be identified as the first anchored transformation of the $L D C$ in Albert's works, precisely because it addresses the very same theme that the $L D C$ does. In order to understand this better, we will examine now this first anchored transformation in detail.

The first solution - that on the question of the celestial soul—is found in the context of Albert's discussions on the third coequal, the empyreal heaven. In article 1, which precedes our question, Albert had identified God as the prime mover of the heavens in reliance on Aristotle's Metaphysics, and referred to Him as "the external mover disproportionate to the moved", and "the first cause outside every genus [...] whose caused things comprise all of creation". ${ }^{44}$ Yet Albert also introduced two other movers, hierarchically beneath God and intrinsic to nature, the so-called forma coniuncta caelo (the second mover) and the forma materialis (the third mover). ${ }^{35}$ With this three-fold division of celestial movers,

32 Albert the Great, De IV coaequaevis, III.16.2, p. 439b: Utrum motor ille qui est intra, et non est divisibilis secundum quantitatem mobilis, sit anima coeli, vel non?

33 Albert the Great, De IV coaequaevis, IV.24.2, p. 475a:Utrum 〈angeli〉 peraliquas species intelligant, et si intelligant per eas, quae sunt illae?

34 Albert the Great, De IV coaequaevis, III.16.1 sol., p. 438a: Dicendum, quod si velimus loqui secundum Philosophos, ponemus in coelo triplicem motorem, scilicet Deum qui est motor extra, non proportionatus mobili. Ibid., p. 439a: Sed prima causa extra genus naturae est Deus, cujus causata sunt omnia creata.

35 Albert the Great, De IV coaequaevis, III.16.1, p. 438b: Secundus motor est forma conjuncta coelo non divisibilis divisione coeli. It is equally true for Albert that the forma coniuncta caelo can be referred to as causa prima; cf. Ibid p. 439a: [...] causa prima dicitur duobus 
Albert revealed his indebtedness to the Peripatetic tradition as well as to the $L D C$, even though he had not yet adopted the latter's four-fold division of the causae primariae of proposition VIII(IX), as he will in his commentary on the $L D C$.

In the following article, our article under consideration, Albert discusses the nature and activity of the two internal celestial movers. Here, in addition to the $L D C$, he cites Aristotle, Moses Maimonides, and Averroes (De substantia orbis $)^{36}$ to support his identification of the forma coniuncta caelo or heavenly intelligence with the 'celestial souls' (animae orbium) ${ }^{37}$ However, it is the $L D C$ with propositions XII(XIII) and XIV(XV) that enables him to distinguish these celestial souls sharply from human souls. Albert thus reasons with the help of the $L D C$ that while the celestial souls cognise by way of fully self-reflexive cognition as propounded in both propositions, this activity remains unachievable for human souls. ${ }^{38}$ This sharp difference in cognitive activity serves Albert subsequently to account for the ontology and causal activity of the celestial souls: each celestial soul possesses the two powers of intellect and moving appetite, each is totally self-sufficient in its existence and in its activity, and each attends to body like "nature to ship, [...] moving and ruling [body]".39 To support this last claim concerning the celestial soul's causal activity, Albert draws yet again on the $L D C$, this time on proposition XXII(XXIII): Omnis intelligentia divina scit res per hoc quod est intelligentia, et regit eas per hoc est divina. ${ }^{40}$ While the causality still remains unclear in this appropriation of the $L D C$, in his reply to

modis, scilicet in genere naturae, et extra genus. In genere naturae motor caeli intra dicitur prima causa, et primum mobile dicitur causatum primum, habens ordinem ad generationem et corruptionem [...]. Sed prima causa extra genus naturae est Deus, cujus causata sunt omnia creata.

36 The entire section that relies on Maimonides' Dux neutrorum II.6, fol. XLII verso here, as well as the previous section are missing in the first redaction of Albert's De IV coaequaevis (MSs. Wien, Dominikanerkloster, 150/120; Lilienfeld, Stiftsbibliothek, 209). This is the case, because when Albert composed the first redaction of his Summa de creaturis, he had access only to a partial translation of Maimonides' Dux neutrorum, namely to his so-called Liber de deo uno benedicto (i.e. Dux neutrorum II, Propositiones XXVI and Capitulum I). Albert retroactively extended his De IV coaequaevis by Maimonides' Dux neutrorum only in the second redaction after he had access to the complete Latin translation of it. Cf. also Rigo 2001.

37 Albert the Great, De IV coaequaevis, III.16.2, p. 443a-b: Sed sivellemus Philosophos ad idem reducere cum Sanctis, dicemus quod quaedam intelligentiae sunt in orbibus deservientes primo in motu orbium, et intelligentiae illae dicuntur animae orbium.

38 Albert the Great, De IV coaequaevis, p. 443b. Cf. also Beierwaltes 1963, p. 202-206.

39 Albert the Great, De IV coaequaevis, III.16.2, p. 443b: Operatur autem ad corpus ut natura ad navem, hoc est, secundum rationem movendi ipsum et regendi $[. .$.$] .$

Albert the Great, De IV coaequaevis, III.16.2, p. 443b. 
argumentum five, Albert finally explains how he envisions it in greater detail, and suggests that the celestial souls "cause all diversity in inferior beings in accordance with nature by their motion of causes", which is based on their selfcognition..$^{41}$ In reliance on proposition VII(VIII) of the $L D C$, Albert determines all knowledge of the celestial souls to be neither particular nor universal, but rather causal. Each celestial soul is "a mover according to the predetermination of its determined work, never in error [...], and always correct in its work, because it never accepts a thing except by the fact that it truly is its cause according to nature."42 But how exactly does Albert envision the causal activity of these celestial souls to occur? And what role does the $L D C$ play in this conception?

To answer these questions, we must turn to Albert's discussion of the fourth coequal, the angels, in which proposition $\mathrm{Ix}(\mathrm{x})$ of the $L D C$ plays an important role. ${ }^{43}$ By identifying the biblical angels with the celestial souls we just consid-

41 Albert the Great, De IV coaequaevis, III.16.2, p. 444b: [...] motores sphaerarum per motum causarum causant omnem diversitatem quae est in inferioribus secundum naturam: et ideo cognoscentes se in quantum causae sunt, cognoscunt naturalia omnia. In his De intellectu et intelligibili this mode of cognition is, however, applied to humans too. Cf. also Albert the Great, De intellectu et intelligibili, II.8, p. 514b-516a.

42 Albert the Great, De IV coaequaevis, III.16.2, p. 444b: haec scientia non est in universali, nec in particulari: per hoc enim quod cognoscunt se, cognoscunt universalia et particularia causata a motoribus suis. Et hoc est quod dicit Philosophus in propositione septima libri de Causis: 'Omnis intelligentia scit quod est supra se, et quod est sub se. Et scit quod est sub se, quoniam est ei causa: et scit quod est supra se, quoniam acquirit ab eo bonitates.' Per hoc etiam patet, quod intellectus motorum completior est intellectu humano, et habent scientiam propter quid: et intellectus eorum est motus secundum praedeterminationem determinati operis, et non erroneus, sicut videtur probare objectio, et semper est rectificatus in opere, eo quod numquam accipit rem, nisi per illud quod est vere causa secundum naturam.

43 The first appearance of proposition 9 in Albert's Summa creaturis takes place in the context of the fourth co-equal, the angel. After discussing the three other co-equals-matter, time, and empyreal heaven-Albert concludes his De IV coaequaevis by a discussion on angels which he identifies with the separate intelligences of the philosophers. Albert's conflation of the angels with the separate intelligences here is no accident, but an explicit choice as part of his early synthetic programme. Inquiring, then, about the simplicity of angels, Albert suggests in his solutio that angels are composed of act, esse, and potency, quod est. In reply to objection seven, which places the angel's simplicity in its capacity for receiving much goodness from the first cause, Albert does not take the intelligible forms infused in the angels as deciding factor. Instead he reasons on the basis of the $L D C$ that these forms are contained in the angels as accidents in it as its subject. The reception of these forms does not determine the nature of the angel in its simplicity or composition, but rather follows upon it (cf. Albert the Great, De IV coaequaevis, IV.21.1, p. 463b). The composition of an angel is assigned to it because of its nature and not because of the way 
ered, Albert grounds their causality in their "deiform" cognition ${ }^{44}$ —deiform for two reasons: on the one hand, because of the forms by which they cognise; on the other hand, because of their peculiar act of cognition. Regarding these forms Albert suggests, this time relying on pseudo-Dionysius and Augustine, that angelic cognition occurs by way of infused intelligible species, a suggestion that clearly foreshadows Aquinas' conception of angelic cognition. ${ }^{45}$ Yet Albert goes beyond the purely cognitive level and identifies these species or formae ad res, as "exemplars of the natural causes" or "seminal rational causes from which all work of nature is produced." 46 This causal conception of the formae ad res in the angels sounds a bit startling, given that we would expect exemplars or seminal causes to be in God. Yet Albert is quick to suggest a significant causal limitation. While God contains the exemplars in identity to His substance and essence and thus has full creative power through them, the angels contain them according to their own property and measure as natural

in which it receives its accidents, namely the forms contained in it (cf. De IV coaequaevis, IV.21.1, p. 465a). The principal purpose of proposition 9 of the $L D C$ here is to strengthen an ontological argument for the composition of angels.

44 Albert the Great, De IV coaequaevis, IV.24.2, p. 477a: Virtus propria est virtus naturalis intelligendi. Et haec virtus dicitur deiformis propter duo, quorum unum est in specie per quam intelligit Angelus, et alterum in actu. In specie quidem: quia species illa est exemplar causarum naturalium secundum ordinem suum secundum quod causae sunt. Ibid., p. 478b: Dicitur ergo intellectus eorum deiformis propter duo, quorum unum est, quia est per formas quae sunt ad res faciendas, sicut est species ideae primae: sed in duobus est differentia, quorum unum est, quod species ideae primae est secundum naturam et proprietatem causae primae exemplar illorum quae fiunt, scilicet quod est idem cum causa prima in substantia, et quod ipsa una existens in numero et essentia, est causa et exemplar omnium cognoscibilium: sed in Angelis est secundum proprietatem et rationem causarum naturalium moventium et transmutantium materiam. Aliud propter quod intellectus Angeli deiformis est, in actu intelligentiae ipsius est: statim enim sine deceptione et inquisitione conspicit quidditates et veritates rerum: et hoc est ideo, quia non obstant intellectui suo phantasiae apparentes in exterioribus quae sunt causae deceptionis in intellectu humano.

45 Cf. for instance Thomas Aquinas, I Sententiarum, 37.4.1, t. 1, p. 88o: Invenitur autem successio in intellectu angeli: quod sic patet. Omnis intellectus qui cognoscit diversa per diversas species, non potest simul actu illa cognoscere, ut ex praedeterminatis patet [dist. 25, quaest. 1, art. 2]. Intellectus autem angeli potest cognoscere res dupliciter, sive duplici specie: scilicet vel in consideratione Verbi, quod est una similitudo omnium rerum, et sic simul potest multa videre; vel per species innatas, vel concreatas rerum, quae sibi inditae sunt, quae plures plurium sunt; unde oportet quod secundum illas species non cognoscat plura simul. Cf. also, for instance, II Sententiarum 3.3.1; II.3.3.3; De veritate 8-9; Summa theologiae I.55-58, I.89. This list is by far not exhaustive.

46 Albert the Great, De IV coaequaevis, IV.24.2, p. 478a: Dico igitur, quod omnes causae istae quoquo modo sint transmutantes et moventes materiam, inditae sunt materiae et naturae in ipsa creatione sex dierum: et has vocat Augustinus seminales. 
causes and thus have limited causal power through them, limited to the motion and change of matter. ${ }^{47}$

Similarly, for Albert the angelic cognition is deiform because of its act, which he identifies as static, immediate, and a certain mode of cognition, full of forms. This last formulation is, of course, a reference to proposition $\operatorname{Ix}(\mathrm{x})$ of the $L C D$ according to which omnis intelligentia plena est formis. ${ }^{48}$ Quoting the commentary to this proposition, Albert thus accounts for the angelic hierarchies: the universality of the forms contained in them gives away the simplicity of their form. Or, the other way around, the simpler the essence, the more universal and the less in quantitative terms the forms of understanding. ${ }^{49}$

47 Albert the Great, De IV coaequaevis, p. 478b: Exemplar igitur causarum transmutantium et moventium materiam secundum quod causae sunt, datum est Angelis in prima creatione eorum, et per illud cognoscunt omnia quae fiunt in materia transmutata.

48 Proposition IX of the $L D C$ - omnis intelligentia est plena formis-features, for the first time in Albert's De incarnatione, by way of an epistemologized reading in the contexts of his angeology and eschatology. By reading it in light of Augustine's understanding of cognitio vespertina angelorum and pseudo-Dionysius' conception of intellectus deiformis, Albert joins together the mode of cognition of the Biblical angels with the mode of cognition for the Peripatetic intelligences. Cf. for instance Twetten 1999, p. 25-62. This epistemological association, which Albert justifies on the basis of the innate formae ad res, strongly affects his early conception of the ontology of celestial intelligences and their causality. In his De incarnatione, however, it simply serves the purpose of defending the mode of cognition of the separated human soul in the afterlife. Albert the Great, De incarnatione, 4.1.1, p. 205.64-76: Item, est notitia angelorum, qua cognoscunt res in verbo, quam beatus Augustinus appellat cognitionem matutinam. Item est alia qua cognoscunt res in seipsis, idest per formas, quas habent apud se a creatione. Sicut enim dicitur in Libro de causis, 'omnis intelligentia est plena formis'. Et hanc cognitionem appellat vespertinam. Tunc autem cognoscunt, sicut dicit Dionysius in VII cap. De divinis nominibus, intellectu deiformi, idest formis datis sibi a creatione, quae sunt similes ideis in mente divina. Talem etiam cognitionem habet anima beata. Quod patet; aliter enim nihil cognosceret non existens in corpore. Albert changes his mind on these formae ad res and replaces this Platonic understanding of formality by a Peripatetic understanding of formality, according to which form is something undetermined. Cf. Albert the Great, Liber de natura et origine animae, II.17, p. 43.85-44.14. We discussed this matter earlier in Krause/Anzulewicz 2017.

49 Albert the Great, De IV coaequaevis, IV.24.2, p. 479a: Quod autem dicitur, quod in quibusdam sunt magis universales, et in quibusdam minus universales, sic intelligitur, quod formae illae sunt simplices magis et minus secundum majorem vel minorem simplicitatem essentiae in Angelis superioribus et inferioribus: quanto enim forma est simplicior, tanto universalior. Et hoc est quod dicit commentum in expositione ejusdem propositionis, quod res non recipiunt formas nisi secundum modum possibilem: et non dicitur magis universalis vel minus, eo quod sit de paucioribus vel pluribus. The universality that Albert describes here is a modal, qualitative universality and not a quantitative universality. Cf. Albert the Great, De IV coaequaevis, p. 48ob: Si autem objicitur, quod supponitur in auctoritate Philosophi supra ex libro 
This is yet again an understanding that Thomas Aquinas will adopt for the remainder of his career. ${ }^{50}$

To sum up Albert's reliance on the $L C D$ in his Summa de creaturis, we find that in explicit reliance on propositions VII(VIII), IX(X), XII(XIII), XIV(XV), and XXII(XXIII) he introduces his conception of the causal activities of the celestial souls or angels. In so doing, he not only distinguishes their cognitive activity from that of humans, but also separates their natural causation through change and motion from God's creative activity ex nihilo. As we learn from the very beginning and very end of the De IV coaequaevis, the relation between the creative activity of God and the natural causality of the celestial souls differs. On the one hand, creation ex nihilo is limited to the world's installation, schematically accounted for by the hexaemeron and causally restricted to an efficient creation of nature "in its principles". On the other hand, following upon this initial installation, divine causality propagated (propagavit) all coming to be "with nature" (cum natura), and perpetually reduced nature's workings to perfection (usque ad perfectionem deduxit opera). ${ }^{51}$ This "mediate creation", as we may call it, is something that Albert openly endorses in reliance on proposition VIII(IX) of the $L D C$, and that he will come to develop as one of his leading philosophical principles, expressed by the well-known formula opus naturae est opus intelligentiae. ${ }^{52}$

As we have seen, the $L D C$ stands at the very heart of Albert's early solution to the question of creation. Its appropriation in Albert's Summa de creaturis, particularly in his De IV coaequaevis, can be identified as an anchored transformation of the insights contained in the $L D C$. Contrary to Albert's dissociated transformation of the $L D C$ in his pre-Parisian phase, the $L D C$ is now granted an autonomous thematic relevance in Albert's works that it did not possess before.

de Causis, quod ille formae sunt universales. Dicendum, quod sunt universales propter simplicitatem, et quia ad omnia naturalia cognoscenda sufficiunt: sed non sunt universales sicut scientia dicitur universalis quae est abstracta a sensibili particulari.

$5^{\circ} \quad$ Cf. Thomas Aquinas passages as quoted in note 44.

51 Albert the Great, De IV coaequaevis, IV.73.10 sol., p. 761b: Dicendum, quod quiescere est ab opere cessare duobus modis, scilicet ex parte operis, et ex parte efficientis. Ex parte operis: quia postea nihil novum fecit, cujus principia naturalia secundum formam vel materiam vel similitudinem in sex diebus non praecesserunt. Ex parte efficientis vero: quia in sex diebus naturam in principiis suis Deus per seipsum instituit. Post vero non per seipsum solus, sed cum natura: et in natura res naturales propagavit: et de hac propagatione intelligitur quod dicitur in Joanne, v, 17. Ad aliud dicendum, quod quies in hac significatione non est lassati, sed artificis qui usque ad perfectionem deduxit opera.

$5^{2}$ This also reveals where Albert devises his later principle opus naturae est opus intelligentiae. Cf. Liber de causis prop. VIII(IX) n. 79-91, p. 66-70, Hödl 1994, p. 132-148, Weisheipl 1980, p. 441-463. 
The insights contained in it are woven into Albert's thought mostly in their original meaning and are no longer formalised or abstracted from their original context as was the case before. Since the aim of Albert's Summa de creaturis differs from the earlier theological works in that it intends to provide a holistic understanding of the world by way of a synthesis of theological and philosophical considerations, it seems to have been a natural move for Albert to take the $L D C$ at face value. Yet Albert's anchored transformation of the $L D C$ in his Summa de creaturis should not only be interpreted in light of his earlier transformations in his previous works but also in light of his ensuing integrations, and particularly in light of his integration of it into his commentary on Peter Lombard's Sentences. For it is in this work, which he composed shortly after his Summa de creaturis, that Albert's use of the $L D C$ takes on a different yet crucial meaning on the path to its systematic relevance for Albert's overall philosophical programme. Indeed, it is in his Sentences that we can witness the turning point in Albert's methodological efforts, away from his conciliatory approach to theology and philosophy and towards a a clear-cut division between both scientific realms.

Albert's Sentences: Systematic Reorientation and the Liber de causis

On the surface, Albert's commentary on Peter Lombard's Sentences (1246) seems to take a stark turn for orthodoxy on the three questions of the angels' ontology, their movement of the heavens, and their involvement in mediate creation. The sensitivity of such topics, particularly in a commentary on Lombard's Sentences, led, as we shall see, to a more prudent treatment of them, which may indeed explain Albert's move away from his earlier conflation of the biblical angels with the Peripatetic intelligences or celestial souls. Devoting an entire question to this 'mistake' of conflation, as he calls it in book II of his Sentences - a mistake which was committed by certain people (quidam) ${ }^{53}$ Albert proclaims that "we shall never fall into the error of saying that angels are necessary for the motion of the heavens." ${ }^{54}$ Likewise, he declares that the

53 In his commentary on the Sentences, II.3.3, p. 64b-66b, Albert devotes an entire article to the question of "Whether we [theologians] call 'angels' those substances that the philosophers call 'intelligences', as some contentiously presume to defend?" Cf. Albert the Great, II Sententiarum 3.15, p. 89a: Item, hoc videtur per illam propositionem in libro de Causis, quod intelligentia est plena formis: ergo videtur, quod similiter Angelus, licet secundum intentionem nostram intelligentia non sit Angelus.

Albert the Great, II Sententiarum 3.1. ad sc 1, p. 61b: Ad aliud autem dicendum, quod insania 
philosophers commit an error maledictus in maintaining that the heavens are naturally moved by the triad of celestial movers: the first cause, the intelligence, and the heavenly soul. ${ }^{55}$ Following the most orthodox theological source of his times, John Damascene's De fide orthodoxa, Albert insists instead "that it should be more truthfully maintained that [the heavens] are only moved by divine command and will", and similarly that "nothing is more safely said than that the [heavens] are moved by the will of God alone, and, by their proper nature, which does not oppose motion."56

These questions comprise a crucial stage in Albert's systematic development, particularly because he now shifts from his conciliatory project between theology and philosophy to the clear division of the two sciences in book II of his Sentences. When Albert began to consider the scientific character of theology here along Aristotelian criteria for the first time, he soon realised that his previous efforts at a conciliatory synthesis between the two sciences could not do justice to either of them. Albert revised his understanding of their relationship as a result, and began to distinguish sharply between them along the Aristotelian criteria of scientific principles, subject matter, unity, and goal. Yet Albert's methodological separation of theology and philosophy did not only result in a legitimation of theology as an independent discipline and a safeguarding of its status as a subject taught at the University of Paris. More importantly, it also gave rise to a far-reaching scientific autonomy of all philosophical

est: quia nos numquam declinabimus in hunc errorem, quod dicimus Angelos esse necessarios ad motum orbium: licet non negemus quin possint movere: sed numerus et ratio creationis non dependet ex illo. Emphasis is ours in translation above.

55 See following note.

56 Albert the Great, II Sententiarum 14.6, p. 265b-266a: Omnes Philosophi Arabum dixerunt et probaverunt multipliciter, quod coelum movetur ab anima conjuncta sibi: et hoc dicit Aristoteles, et Avicenna, et Averroes, et Algazel, et Alpharabius, et Maurus Albumasar, et Rabbi Moyses, et quod habet motorem triplicem, scilicet causam primam quae est desideratum primae intelligentiae quae est plena formis explicabilibus per motum sui orbis: sed quia intelligentia simplex est, ideo non potest intendere motum particularem in hoc et illo situ, et ideo tertius motor conjunctus coelo est anima secundum ipsos, et natura coeli est dispositio ad motum: quia naturaliter circulariter fertur, et in compositione non est contrarietas: et ideo motus ille est sine labore et poena, ut dicunt, et non inducit lassitudinem ut motus animae quo movet corpus nostrum. In hoc ergo concordant omnes, et quod virtus primi motoris est in omnibus inferioribus, et secundi in inferioribus sibi, et sic descensio. Quod autem hoc totum sit error maledictus, patet per Damascenum sic dicentem: 'Nullus autem multos coelos vel luminaria existimet: inanimati enim sunt et insensibiles.' Et ideo verius dicendum puto, quod non moventur nisi jussu divino, et voluntate: et quod rationes supra dictae non probant, nisi quod non moveantur a natura quae sit forma corporis movens: et hoc dicunt etiam alii Philosophi sicut Astronomi, et Ptolemaeus, et Albategni, et Albumasar, et Geber, et alii quamplures. Cf. also Rigo 2005, p. 349-354. 
disciplines and granted them a scientific standing of equality as opposed to than their previous reduction under theology. Accordingly, when Albert recapitulates his earlier scholarly efforts in book II of the Sentences on creation, he distances himself from his reductionism and explains that "elsewhere still much was discussed concerning this matter, and [it was done so] extensively; yet there, we were following what certain masters of theology said, who wished to reduce the opinions on the natural [sciences] to theology." ${ }^{\prime 57}$

There is no surprise then, that, inasmuch as Albert refrains from reducing philosophy to theology, he also refrains from conflating the angels with the celestial intelligences in his commentary on the Sentences, a separation that he will maintain for the remainder of his career. ${ }^{58}$ But there is another reason than the systematic one in Albert's eyes that the angels should be distinguished from the celestial intelligences: angels cannot be considered celestial movers and causes, because their missions as described in the Bible differ fundamentally from the propagative purposes of the celestial intelligences described in the $L D C$ (and of course by other philosophical thinkers in the Peripatetic tradition). ${ }^{59}$ Aristotelian method as applied to theology and Biblical content thus provided Albert with strong reasons for distinguishing angels from celestial intelligences from the mid-1240s onwards. The status and purpose of the angels within theology was thus restored in a traditional sense. Yet what did Albert have to say about the celestial intelligences in his theology, their ontological status, and their purpose in moving the heavens and mediating creation?

57 Albert the Great, II Sententiarum 14.6, p. 266b: Alibi etiam disputatum est de ista materia multum et prolixe: et ibi secuti sumus dicta quorundam Magistrorum theologiae, qui voluerunt opiniones naturalium ad theologiam reducere. Cf. Anzulewicz 2011, p. 392397 .

$5^{8}$ Albert the Great, De causis et processu universitatis a prima causa, I.4.8, p. 58.19-29: Ordines autem intelligentiarum, quas nos determinavimus, quidam dicunt esse ordines angelorum et intelligentias vocant angelos. Et hoc quidem dicunt Isaac et Rabbi Moyses et ceteriphilosophi Iudaeorum. Sed nos hoc verum esse non credimus. Ordines enim angelorum distinguuntur secundum differentias illuminationum et theophaniarum, quae revelatione accipiuntur et fide creduntur et ad perfectionem regni caelestis ordinantur in gratia et beatitudine. De quibus philosophia nihil postest per rationem philosophicam determinare. Ibid., II.5.24, p. 191. 30-192.6: Scimus etiam, quod quidam contendunt spiritus, qui vulgariter angelivocantur, intelligentias esse. Sed hoc certum est, quod angeli intellectuales substantiae sunt secundum ministeria gratiae distributae. Sed quod hoc modo intelligentiae sint, quo intelligentiae a Peripateticis ponuntur, scilicet quod immobiles sint loco et operatione, penitus absurdum est et non convenit cum dictis eorum qui de motibus et apparitionibus et operationibus angelorum locuti sunt.

See previous note. 
This question leads us to the heart of Albert's unique appropriation of the $L D C$ in his Sentences. His main point in this regard was to propose that the question of celestial motion and causality as exerted by the separate intelligences does not fall under the domain of theology as propounded in the Sentences.

Those things, however, that are presented in the Liber de causis ought to be avoided, because the philosophers who speak of the intelligences posit them to be causes [of things in the world] ${ }^{60}$

Albert's suggestion here of avoiding the $L D C$ 's views on the propagation of the celestial intelligences in the theology of the Sentences does not mean that this theme does not fall under theology per se. Indeed, as we saw in the previous section of this paper, Albert's synthetic worldview in his Summa de creaturis allowed him explicitly to incorporate insights of the $L D C$ into his theology, and most prominent among them was the propagation of the celestial intelligences. The general distinction that needs to be drawn to solve this seeming dilemma is that Albert's theology as promulgated in his commentary on the Sentences needed to fulfil obligations of adherence to Biblical authority and traditional orthodoxy. His discussion of creation was thus controlled by standards that were not his own; standards that differed noticeably from the wider conception of theology that Albert's own theological works set forth. In contrast his own standards embraced a much greater scope of authoritative texts and explicitly included philosophical sources without a forced reinterpretation such as the $L D C$. When, in his Sentences, Albert thus propounds an orthodox interpretation of creation and rejects the relevance of the $L D C$ for his understanding thereof, this does not mean that he reverses his positive attitude toward the relevance of the $L D C$ for the truth of the matter of creation. On the contrary,

6o Albert the Great, II Sententiarum 3.15, p. 92a-b: Ad id autem quod objicitur de libro Causarum cavendum est: quia Philosophi loquentes de intelligentiis posuerunt eas esse causas: intelligentia enim plena formis explicabilibus per motum alicujus orbis, in quantum est plena formis, desideratur a motore orbis, et movet ipsum sicut desideratum desiderans: et ideo intelligentia primi ordinis habet formas magis universales et simplices, quae explicantur per motum primum unum et simplicem in mobili uno et simplici: et intelligentia secundi ordinis erit plena formis explicabilibus motu obliqui circuli duplici, et minus universalibus: et sic descendendo: quia sic intelligit Philosophus, quod omnia intelligibilia intelligit: quod est super se, quia causatur et informatur ab illo: et quod sub se est, quia ipsa est causa illi secundum illam rationem quod omnis forma est ex splendore intelligentiae super informatum forma illa. Sed hoc nos ridiculum reputamus: quia non loquimur sic de Angelis, sed potius ponimus eos substantias separatas, non determinatas ad mobile aliquod: et ideo dicimus eos habere formas quas Creator indidit eis ad cognoscendum res hujus mundi, unumquodque in propria natura, et communi, sicut volunt. 
we find that when he revisits the question in his De caelesti hierarchia, Albert is outspoken again about the celestial intelligences, and reasons that it is plausible to regard them as the proximate movers of the heavens. ${ }^{61}$ In his Super Ethica and all his following works, Albert openly affirms the existence of the celestial intelligences and their causal propagative activities, and maintains this view too for the remainder of his career. ${ }^{62}$

61 Albert the Great, Super Dionysium De caelesti hierarchia, c. 11, p. 172.28-46: Sed haec opinio non sustinetur propter tria secundum fidem. Primo, quia non ponimus corpora superiora moveri ab anima, sed a deo vel etiam forte per ministerium angelorum, quamvis etiam philosophi ponant praeter animam, quam dicunt motorem propinquum, intelligentiam esse motorem remotum, ministrantem animae conceptiones ad motum, sicut etiam in nobis fit. Secundum est, quia nos ponimus angelos ministrare deo in spiritualibus ministeriis et circa nos, descendendo de caelo ad nos et non tantum in motu sphaerarum. Tertium est, quia sicorpora superiora haberent animas, oporteret esse tres ordines beatorum, scilicet angelorum et illarum animarum et nostrarum, et quod mererentur per motum. Et haec non sunt consona fidei, quamvis Hieronymus dicat super principium Ecclesiastis, quod sunt superiora corpora animata; sed glossandum est, quia habent actum animae, scilicet motum, quamvis a sanctis nihil contra hanc opinionem dicatur, sed tantum a magistris. Parallel passages: Albert the Great, Super Dionysium De divinis nominibus, c. 4, p. 152.32-37: Nec differt ad propositum, utrum moveatur sola voluntate divina aut quibusdam motoribus separatis, sicut angelis in hoc deo ministrantibus, aut etiam motoribus intrinsecis, qui sint animae eorum, secundum quod ponebant philosophi. Albert the Great, II Sententiarum 2.1 ad 5, p. 45a-b: Ad aliud dicendum, quod illa ratio procedit ex opinionibus Philosophorum, et fundatur partim super dubias propositiones, partim etiam super falsas secundum nostram fidem. Dubium enim est quis sit motor coeli. Ptolemaeus, et Albategni, et Albumasar, et omnes astronomi dicunt coelum moveri a voluntate Dei, et haec est nostra confessio. Aristoteles autem et omnes naturales Philosophi dicunt ipsum moveri ab intelligentia, sicut desiderans movetur a desiderato, et utrum Angeli deserviant Deo in motu orbium, vel non, incertum est nobis: hoc tamen certissime tenemus secundum sanctos Patres, quod non omnes occupantur circa motum coelorum, etiamsi tot essent coeli quot sunt stellae, sicut quidam eorum praesumpserunt dicere: quia nobis traditur quosdam assistere, quosdam circa nos ministrare: tamen quod quidam etiam moveant coelum, videtur secundum expositionem unius sancti per illud verbum Matthaei, XXIV, 29: 'Et virtutes coelorum commovebuntur'. Hoc enim in libro ad Eugenium Bernardus exponit de Angelis.

62 Cf. Albert the Great, Super Ethica, vi.6, p. 435.83-436.3; ibid. vi.8 sol., p. 448.70-449.8, and most aptly: ibid., p. 449.52-64: Ad tertium dicendum, quod plenitudo illa non significat aliquam receptionem formarum, sed quia ipsa inteIligentia est thesaurus indeficiens profundens formas in naturam et in animam, quia utraque est instrumentum eius. Nec per hoc dicimus intelligentias creare animas nec aliquid aliud, quia creatio est operatio primiagentis, quod operatur principalius in omnibus sequentibus, sed creata ultima a primo agente habent etiam aliquid a secundis agentibus. Propter quod etiam Plato posuit processum per quosdam circulos ad similitudinem motus caeli, ut dicitur in I De anima quia a quolibet motore orbis aliquid accipit. Two further developments in Albert's commentaries on pseudo-Dionysius' De caelesti hierarchia and Aristotle's Ethics seem noteworthy. In the former, Albert sharpens his distinction between the hierarchy of the angels, as mansion of the Christian God 
This suggests that Albert's understanding of the conciliability of faith and reason, of theological truth with philosophical truths was other than that of some of his contemporaries. For him, faith was open to rational arguments that decidedly extended, broadened, and advanced contemporary understandings of revealed truth, more often than not well beyond the tastes of traditionalists, as in the case of the $L D C$ 's view on celestial propagation. The decided advantage of Albert's understanding of theology as a flexible enterprise was that there could not be any contradiction between faith and reason. Theology's boundaries were permeable rather than impenetrable in Albert's eyes; they gave space to breathe the air of philosophy, and to inhale it into its system.

A second advantage, which resulted from Albert's rejection of any possible contradiction between faith and reason within theology, was the freedom it created for the use of philosophical works in their original meaning, content, and systematic relevance independently of theology. This philosophical autonomy extended most importantly to the $L D C$, for it was this treatise that eventually came to present the methodologically crowning achievement of Albert's overall philosophical programme. Albert's anchored transformation of the $L D C$ in his Sentences marks a crucial step on the path to this autonomy and significance of the $L D C$. For it is in this work that Albert moves away from welcoming the $L D C$ as a treatise in service of theology to appreciating the intrinsic value of its insights on its own grounds, an appreciation that was required to clear the way for the developments later to come.

\section{5}

\section{Concluding Remarks}

Without hesitation, then, we conclude that the $L D C$ permeates Albert's corpus from its very beginnings until its very end, but it does so in different contexts, in different ways, and with different ends. Initially, Albert integrated the $L D C$ by way of decontextualizing transformations of select propositions into the context of genuinely biblical theological subject matters with the purpose of achieving a better understanding of these unrelated subject matters. Then, in

and the saints, in opposition to the hierarchy of the intelligences, as cosmological and supralunary realm of the universe (cf. Anzulewicz 1998, p. 276-281). In the latter, Albert explicates in detail proposition $\mathrm{V}$ (VI) of the LDC—Deus est supra omne nomen-reasoning that God can only be named by the first being caused, the intelligence, and thereby implying that God is beyond intellection. Cf. Albert the Great, Super Ethica, vi.8, p. 446.81-84: 'Causa prima', ut dicitur in Libro de causis, 'est supra narrationem,' sed nominatur nomine causati sui primi, quod est intelligentia, quae maxime vicinatur sibi. 
his first theological Summa de creaturis, Albert grounded structure and content in the biblical gloss on Genesis and interpreted the major theme of propagation as preceded by creation in implicit reliance on the creative system of the $L D C$, as well as in explicit reliance on half of the $L D C$ 's propositions. ${ }^{63}$ Here, Albert appropriated the $L D C$ by way of an anchored transformation and preserved the original meaning of central themes contained in it, but he did so with the decided purpose to conciliate the $L D C$ 's philosophical truths with the theological truths as contained in the Bible and Christian tradition. Finally, Albert's systematic separation of philosophy and theology in his commentary on the Sentences led him to a renewed and more authentic appreciation of the $L D C$ in his works to follow. While he seemingly rejected the $L D C$ 's thematic relevance for the question of creation within the traditional theological context of his qualifying work on the Sentences, he nonetheless paved the way for the $L D C$ 's philosophical liberation in the works to come. His clear discrimination between, on the one hand, the being and roles of biblical angels and, on the other hand, the being and roles of the celestial intelligences, allowed him to come to an improved appraisal of the $L D C$ 's importance on the levels of content and method. At the end of this long journey, the $L D C$ thus attained the highest possible significance in Albert's scientific edifice due to its foundational purpose for his philosophia realis.

Thematically speaking, it would, nonetheless, be fair to say that the $L D C$ has stood at the heart of Albert's thought ever since its earliest anchored transformation in his Summa de creaturis. Far from the double truth or double standards, Albert's unique appropriation of the $L D C$, particularly in his early works of the Summa de creaturis and the Sentences, is truly a significant intellectual achievement in the history of Aristotelian philosophy, ${ }^{64}$ an achievement whose effects and influence on later thinkers and especially his student, the young Thomas Aquinas, is yet to be fully appreciated.

63 Albert the Great, De IV coaequaevis, I.2 divisio textus, p. 319; cf. also Gilson 1955, p. 375384 . This is not a systematic theology after the model of Peter Lombard, but takes up the earlier conception of the Hexaemeron: Thierry of Chartres and School of Chartres; Albert connects this earlier tradition (Platonic-biblical tradition) with Aristotle, Augustine (De Genesi ad litteram) and Philip the Chancellor (Summa de bono), and thus stands at a transition within the Christian theological tradition.

64 'Aristotelian philosophy' as Albert himself saw it. 


\section{Appendix 1}

\section{Liber de causis}

Prop. I

Prop. II

Prop. III

Prop. IV

Prop. (v)

Prop. v(VI)

Prop. VI(VII)

Prop. VII (VIII)

Prop. VIII(IX)

$\operatorname{Prop} \operatorname{Ix}(\mathrm{x})$

Prop.XII(XIII)

Prop XIII(XIV)

Prop. XIV(XV)

Prop. $\operatorname{XIX}(\mathrm{Xx})$

Prop. $\mathrm{XX}(\mathrm{XXI})$

Prop. XXII(XXIII)

Prop. XXIII(XIV)

Prop XXVI(XXVII)

Prop. $\operatorname{xxx}(\mathrm{xxxI})$ [?]

\section{Albertus Magnus}

De IV coaequaevis I.1.1, p. 308b; II.4.1, p. 36oa; De homine, p. 53.3-20; p. 85.11-17; p. 86.63-74; 595.32-49.

De IV coaequaevis II.3.3, p. 351b; IV.70, p. 723a.

De homine, p. 75.47-49; p. 76.61-69; p. 96.20-69; p. 39o.3o-37;

p. 409.42-52; p. 471.66-472.3; impl. p. 75.9-12.

De IV coaequaevis I.2.1, p. 320 sq.; De homine, p. 459.46-57;

p. 584.14-35; impl. p. 588.28-36.

impl. De homine, p. 414.1-15.

De homine, p. 424.29-38.

De IV coaequaevis IV.21.1, p. 462a; IV.38.1, p. 552a.

De IV coaequaevis III.16.2, p. 444b; De homine, p. 41.69-42.15.

De IV coaequaevis I.1.3, p. 312b; De homine, p. 65.39-50;

p. 92.32-38; p. 410.57-411.7.

De IV coaequaevis IV.21.1, p. 465a; IV.24.2, p. 479a; p. 48ob; De homine, p. 390.30-37; p. 428.58-62; impl. p. 411.66-412.14. De IV coaequaevis III.16.2, p. 443b; IV.63.1, p. 669a; De homine, p. 420.45-48; p. 426.62-427.4.

De homine, p. 75.55-6o; 76.61-69.

De IV coaequaevis III.16.2, p. 443b; De homine, p. 420.49-53;

p. 422.20-25.

De homine, p. 424.29-33.

De IV coaequaevis III.16.3, p. 446b; impl. De homine, p. 584.5152.

De IV coaequaevis III.16.2, p. 443b.

De IV coaequaevis I.1.1, p. 310a; III.11.2, p. 422b.

De IV coaequaevis IV.20.1, p. 459a; De homine, p. 470.35-38.

De IV coaequaevis II.3.1, p. 339a; II.3.4, p. 353b; cf. I Sententiarum 8.8, p. 231a; 9 divisio textus, p. 271a; Super Dionysium De divinis nominibus c. 10, p. 396.36-38 


\section{Bibliography}

\section{Primary Sources}

Albert the Great, Buch über die Ursachen und den Hervorgang von allem aus der ersten Ursache/Liber de causis et processu universitatis a prima causa, H. Anzulewicz et al. (trans. and eds.), Hamburg, 2006.

Albert the Great, De causis et processu universitatis a prima causa, ed. W. Fauser, Opera omnia, ed. Colon. XVII/2, Münster, 1993.

Albert the Great, De homine, eds. H. Anzulewicz / J.R. Söder, Opera omnia, ed. Colon. XXVII/2, Münster, 2008.

Albert the Great, De incarnatione, ed. I. Backes, Opera omnia, ed. Colon. XXVI, Münster, 1958.

Albert the Great, De intellectu et intelligibili, ed. A. Borgnet, Opera omnia, ed. Paris IX, Paris 189o, p. 477-521.

Albert the Great, De natura boni, ed. E. Filthaut, Opera omnia, ed. Colon. xxv/1, Münster, 1974 .

Albert the Great, De resurrectione, ed. W. Kübel, Opera omnia, ed. Colon. XXVI, Münster, 1958.

Albert the Great, De sacramentis, ed. A. Ohlmeyer, Opera omnia, ed. Colon. XXVI, Münster, $195^{8 .}$

Albert the Great, Super Ethica, VI-IX, ed. W. Kübel, Opera omnia, ed. Colon. XIV/2, Münster, 1987 .

Albert the Great, Liber de natura et origine animae, ed. B. Geyer, Opera omnia, ed. Colon. XII, Münster, 1955 .

Albert the Great, Metaphysica, I-V, ed. B. Geyer, Opera omnia, ed. Colon. XVI/1, Münster, 1960 .

Albert the Great, Metaphysica, VI-XIII, ed. B. Geyer, Opera omnia, ed. Colon. XVI/2, Münster, 1964.

Albert the Great, Physica, I-IV, ed. P. Hossfeld, Opera omnia, ed. Colon. IV/1, Münster, 1987.

Albert the Great, Problemata determinata, ed. I. Weisheipl, Opera omnia, ed. Colon. XVII/1, Münster, 1975 .

Albert the Great, [Sent. I:] Super I librum Sententiarum, dist. 1-3, ed. M. Burger, Opera omnia, ed. Colon. XXIX/1, Münster, 2015 .

Albert the Great, Commentarii in I Sententiarum (dist. I-XXV), ed. A. Borgnet, Opera omnia XXV, Paris, 1893 .

Albert the Great, Commentarii in I Sententiarum (dist. XXVI-XLVIII), ed. S.C.A. Borgnet, Opera omnia XXVI, Paris, 1893.

Albert the Great, Commentarii in II Sententiarum, ed. S.C.A. Borgnet, Opera omnia XXVII, Paris, 1894. 
Albert the Great, Commentarii in IV Sententiarum (dist. XXIII-L), ed. S.C.A. Borgnet, Opera omnia xxx, Paris, 1894.

Albert the Great, Super Dionysium De caelesti hierarchia, ed. P. Simon/W. Kübel, Opera omnia, ed. Colon. Xxxvi/1, Münster, 1993 .

Albert the Great, Super Dionysium De divinis nominibus, ed. P. Simon, Opera omnia, ed. Colon. XXXVII/1, Münster, 1972.

Albert the Great, Super Matthaeum, ed. B. Schmidt, Opera omnia, ed. Colon. XXI/1-2, Münster, 1987.

Aristoteles Graece, Ex recensione I. Bekkeri ed. Academia Regia Borussica, I-II, Berlin, 1831.

Averroes, Commentarium magnum in Aristotelis De anima libros, rec. F.S. Crawford, Cambridge (Mass.), 1953.

(Ps.-) Dionysius the Areopagite, De divinis nominibus, ed. B.R. Suchla, Berlin / New York, 1990.

(Ps.-) Dionysius the Areopagite, Dionysiaca. Recueil donnant l'ensemble des traductions latines des ouvrages attribués au Denys de l'Aréopage, I, Bruges, 1937.

Liber de causis - A. Pattin, "Le Liber de causis. Édition établie à l' aide de 90 manuscrits avec introduction et notes", in Tijdschrift voor Filosofie 28 (1966), p. 90-203.

Moses Maimonides, Dux neutrorum, ed. A. Iustinianus, Paris 1520 [repr. Minerva, Frankfurt a. M. 1964].

Petrus de Prussia, Vita B. Alberti Magni Doctoris Magni ex Ordine Praedicatorum Episcopi Ratisponensis, Antwerpen 1621.

Thomas Aquinas, Scriptum super libros Sententiarum Magistri Petri Lombardi episcopi Parisiensis, ed. P. Mandonnet, I, Paris 1929.

\section{Secondary Sources}

Anzulewicz, H. (1998), "Perspektive und Raumvorstellung in den Frühwerken des Albertus Magnus", in J.A. Artsen, A. Speer (eds), Raum und Raumvorstellungen im Mittelalter, Berlin / New York, p. 249-286.

Anzulewicz, H. (1998), "Zur Theorie des menschlichen Lebens nach Albertus Magnus. Theologische Grundlegung und ihre bioethischen Implikationen", in Studia Mediewistyczne, 33, p. 35-49.

Anzulewicz, H. (2000), "Die Rekonstruktion der Denkstruktur des Albertus Magnus", in Theologie und Glaube, 9o, p. 6o2-612.

Anzulewicz, H. (2010), “The Systematic Theology of Albert the Great”, in I.M. Resnick (ed.), A Companion to Albert the Great. Theology, Philosophy, and the Sciences, Leiden / Boston, p. 15-67.

Anzulewicz, H. (2011), "Alberts Konzept der Bildung durch Wissenschaft", in L. Honnefelder (ed.), Albertus Magnus und der Ursprung der Universitätsidee. Die Begegnung der Wissenschaftskulturen im 13. Jahrhundert und die Entdeckung des Konzepts der Bildung durch Wissenschaft, Berlin, p. 382-397, p. 538-548. 
Anzulewicz, H./Rigo, C. (2002), "Reductio ad esse divinum. Zur Vollendung des Menschen nach Albertus Magnus", in J.A. Aertsen / M. Pickavé (eds), Ende und Vollendung. Eschatologische Prespektiven im Mittelalter, Berlin / New York, p. 388416.

Baumgarten, A. (2003), "L' interprétation de la proposition 90 [VIII (IX), n. 9o, ed. Pattin] du Liber de causis chez Albert le Grand et saint Thomas d'Aquin", in Chôra, 1, p. 161-171.

Beierwaltes, W. (1963), "Review: Der Kommentar zum 'Liber de causis' als neuplatonisches Element in der Philosophie des Thomas von Aquin", in Philosophische Rundschau, 11, p. 192-215.

Caparello, A., "Lettura terminologica di un testo albertino. Frammenti graeci", in Sapienza 49, p. 65-84.

D’Ancona Costa, C. (1990), “Causa prima non estyliathim. Liber de Causis, prop. 8[9]: le fonti e la dottrina”, in Documenti e studi sulla tradizione filosofica medievale, 1, p. 327351.

"Einleitung. Zeittafel" (2011), in Albertus-Magnus-Institut (ed.), Albertus Magnus und sein System der Wissenschaften. Schlüsseltexte in Übersetzung Lateinisch-Deutsch, Münster, p. 9-31.

Fidora, A., Niederberger, A. (2001), Von Bagdad nach Toledo. Das "Buch der Ursachen" und seine Rezeption im Mittelalter, Mainz.

Gilson, E. (1955), "Les coaequeva”, in Medioevo e Rinascimento. Studi in onore di Bruno Nardi, vol. I, Firenze, p. 375-384.

Hödl, L. (1994), “Opus naturae est opus intelligentiae. Ein neuplatonisches Axiom im aristotelischen Verständnis des Albertus Magnus”, in F. Niewöhner, L. Sturlese (eds), Averroismus im Mittelalter und in der Renaissance, Zürich, p. 132-148.

Krause, K. (2015), "Transforming Aristotelian Philosophy: Alexander of Aphrodisias in Aquinas' Early Anthropology and Eschatology", in Przeglad Tomistyczny 21, p. 175217.

Krause, K., Anzulewicz, H. (2017), "Albert der Große und sein holistisches Konzept der menschlichen Erkenntnis", in T. Iremadze, U. Jeck (eds), Veritas et subtilitas. Truth and Subtlety in the History of Philosophy. Essays in memory of Burkhard Mojsisch (1944-2015), Amsterdam, forthcoming.

Leinsle, U. (2010), Introduction to Scholastic Theology, trans. by M.J. Miller, Washington D.C.

Madec, G. (1984), "Yliatim", in Archivum Latinitatis Medii Aevi, 43, p. 119-121.

Rigo, C. (2005), "Zur Redaktionsfrage der Frühschriften des Albertus Magnus", in L. Honnefelder et al. (eds), Albertus Magnus und die Anfänge der Aristoteles-Rezeption im lateinischen Mittelalter. Von Richard Rufus bis zu Franciscus de Mayronis, Münster, p. 325-374.

Rigo, C. (2001), "Zur Rezeption des Moses Maimonides im Werk des Albertus Magnus”, 
in W. Senner et al. (eds), Albertus Magnus. Zum Gedenken nach 8oo Jahren: Neue Zugänge, Aspekte und Perspektiven, Berlin, p. 29-66.

Taylor, R.C. (1979), "St. Thomas and the Liber de causis on the Hylomorphic Composition of Separate Substances", in Medieval Studies, 41, p. 506-513.

Taylor, R.C. (1998), "Aquinas, the Plotiniana Arabica, and the Metaphysics of Being and Actuality", in Journal of the History of Ideas, 59, p. 217-239.

Twetten, D. (1999), "Albert the Great's Early Conflations of Philosophy and Theology on the Issue of Universal Causality", in R.E. Houser (ed.), Medieval Masters: Essays in Memory of Msgr. E.A. Synan, Houston, p. 25-62.

Vuillemin-Diem, G. (1975), "Die Metaphysica media. Übersetzungsmethode und Textverständnis", in Archives d'Histoire Doctrinale et Littéraire du Moyen Age, 42, p. 7-69. Weisheipl,J.A. (1980), “The Axiom 'Opus naturae est opus intelligentiae' and its Origins”, in G. Meyer, A. Zimmermann, P.-B. Luttringhaus (eds), Albertus Magnus Doctor universalis 1280/198o, Mainz, p. 441-463. 